\title{
国际主要科学基金机构在地球科学领域的学科布局与 申请导向
}

\author{
张朝林*，郑袁明，王西勃，熊举坤，张利兰，周卿伟，李若男 \\ 国家自然科学基金委员会地球科学部，北京 100085 \\ *联系人, E-mail: zhangcl@nsfc.gov.cn
}

国家自然科学基金委员会(National Natural Science Foundation of China, 简称 NSFC)自 1986 年成立以来，秉 承引导科学发展, 服务学科管理的宗旨, 在吸收借鉴多国 科学基金学科布局和申请导向方式的基础上, 形成了现有 学科布局和申请代码体系. 科学基金的申请导向方式主要 是以学科申请代码引导为主(如面上、青年、地区科学基金 项目的申请及所有项目的归口管理)、指南引导为辅(如重 点、重大、重大研究计划及联合基金等项目申请). 随着科 学技术的发展, 新一轮科技革命和产业变革正在重构全球 创新版图, NSFC 坚持以构建理念先进、制度规范、公正高 效的科学基金治理体系为目标, 将优化学科布局作为新时 代科学基金深化改革的三大核心任务之一. 学科申请代码 作为形成合理基础研究资助格局、促进学科均衡发展、鼓 励学科交叉和发展新兴方向的指南, 对其合理优化无疑是 保障科学基金深化改革事业成功的抓手和关键. 在 1986 2020 年的 30 余年间, NSFC 地球科学部的学科体系 及申请代码经历了 6 次调整, 由初期的 5 个一级学科申请 代码, 发展到目前 7 个一级学科申请代码, 95 个二级申请 代码, 65 个三级申请代码的细分代码体系 ${ }^{[1]} .2018$ 年以来, NSFC 地球科学部地理学科和大气学科先后在申请代码优 化方面进行了尝试, 为我国地球科学领域申请代码和学科 布局优化提供了成功范例 ${ }^{[2,3]}$, 但要全面推进地球科学现 有 7 个学科的申请代码改革, 全面优化地球科学领域的学 科布局, 客观上需要对国际科学基金机构在地球科学领域 的学科布局和申请导向方式进行全面调研, 充分吸收和借 鉴国际先进理念和经验, 结合中国科学基金的发展实际进 行方案设计. 本文对比分析了国际主要科学基金资助机构 在地球科学领域的学科布局与申请导向情况, 结合 NSFC 地球科学基金事业探讨了通过代码改革推进学科布局优 化的可行性与必要性.

\section{1 指导思想和技术方案}

以国际化视野、学科布局和申请导向并重为指导思想, 首先对国际主要的科学基金资助机构(分布见图 1)在地球

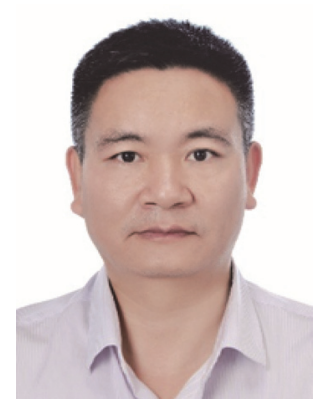

强朝林博士, 国家自然科学 基金委员会研究员，主要从事气象 学和科学基金管理研究工作.

科学领域的学科布局和申请导向方式进行深人分析，然后以 NSFC 地球科学部现有的申请代码设置的层级结构为基准, 进行归类与综合比对, 最后对 NSFC 地球科学学科布局的 优化和基金申请代码改革的可行性与必然性进行了探讨.

\section{2 国际地球科学领域的学科布局与中请引导}

调研发现，国际主要科学基金资助机构对地球科学领 域学科的布局和管理, 主要包括申请指南引导、粗放申请 代码引导或细分申请代码引导，其中，美国、英国和韩国 以申请指南引导为主, 日本和法国以粗放申请代码引导为 主，而欧洲各国、德国、澳大利亚、新西兰和中国主要以 细分申请代码引导为主. 下面对各类别学科布局与申请引 导的特点和方式进行详细阐述.

\section{1 申请指南引导方式}

美国、英国和韩国对基础科学研究项目的申请均属于 指南引导. 由于英国科学基金会的学科布局与申请引导与 美国非常类似, 因此, 仅以美国为代表进行重点介绍. 韩 国因有自己独有的特点, 也进行单独详细介绍.

\section{1 .1 美国国家科学基金会}

美国国家科学基金会(National Science Foundation of United States, NSF)是美国独立的联邦机构，核心任务是资 助除医学以外的所有科学和工程领域的基础研究和教育. 
主要资助人才、创新思想和工具类项目, 尤其注重创新思

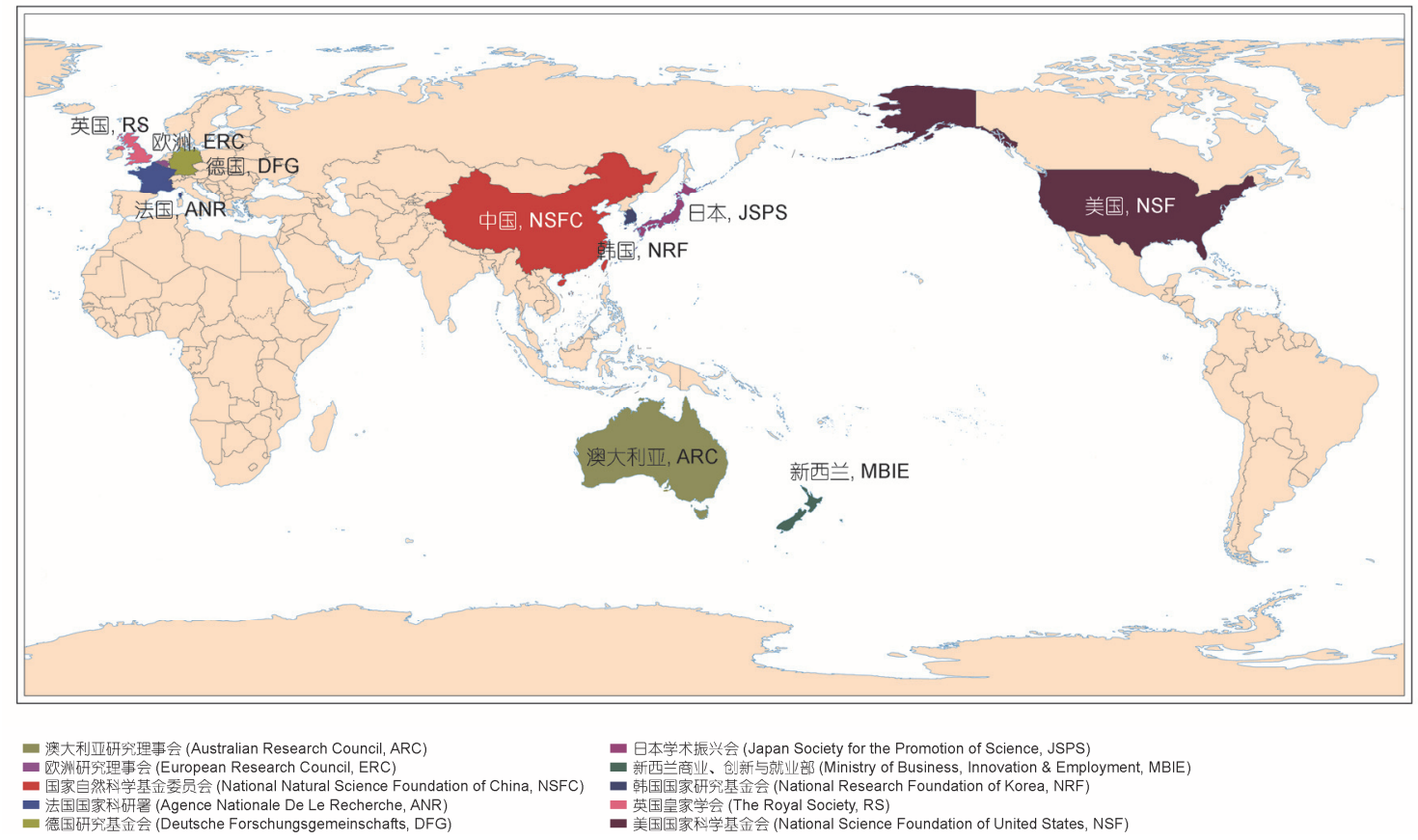

图 1 调研的国际主要科学基金资助机构

Figure 1 The leading international science foundations and agencies involved in this study

维和创新人才的资助培养, 以增强基础研究实力, 培训、 吸引、招募和持续支持世界优秀的科学家从事自然科学基 金研究. NSF 核心组织机构包括 7 个科学部和 7 个职能局 室, 共设置 10 个一级代码、35 个研究领域, 以发布指南的 方式征集科技项目.

其中, 地球科学部(Directorate for Geosciences, GEO) 主要资助大气和空间科学、固体地球科学、海洋科学和极 地科学 4 个领域. 支持推动知识前沿及技术创新的基础研 究, 提高人类对全球环境过程的认识, 如大气和海洋在气 候中的作用、地球水循环和海洋酸化等过程; 支持优先研 究领域的跨学科研究, 如理解、适应和减轻全球变化的影 响; 发展和部署综合海洋观测能力, 支持生态系统的管理; 了解未来淡水的可用性. 预测和理解地震、龙卷风、揕风、 海啸、干旱和太阳风暴等自然环境灾害, 挽救生命和保护 财产. 同时支持跨大气和空间科学、固体地球科学、海洋 科学和极地科学的研究. 作为美国在极地地区基础研究的 主要支持者, GEO 为美国极地活动提供跨部门领导 (https://www.nsf.gov/dir/index.jsp?org=GEO).

GEO 下设 4 个学科处室, 分别管理大气和空间科学、 固体地球科学、海洋科学和极地科学. 每个研究领域的指 南均包含基础学科、整合活动、基础设施、教育以及部门 合作类项目, 而基础研究的资助主要体现在学科计划和整 合活动类项目. GEO 的 4 个领域共设 29 个研究类项目指南, 此类项目主要资助与地球科学类相关学科, 如大气化学、
古气候学、沉积学、生物海洋科学等基础学科, 同时也包 括地球科学前沿等整合活动类研究. 为了提高地球科学领 域教育和培训的质量, 加强各学科领域人才的多样性, 提 高公众对地球系统综合组分知识的了解, GEO 还设有教育 基金、博士后基金、教师奖励基金等人才类基金，以保证 GEO 领域人才的延续. 另外一大类项目资助是工具类研究 项目, 侧重于仪器和基础设施建设、数据管理系统等研究 工具的研发. 此外, 约 $0.5 \%$ 的经费用于资助探索类项目 (exploratory research)、0.5\%用于资助应急项目 (rapid response research)(以上数据均采自 2020 年).

\subsection{2 韩国国家研究基金会}

韩国国家研究基金会(National Research Foundation of Korea, NRF) 是韩国主要的科研资助机构之一, 以指南引导 进行资助. 旨在为所有学科的基础研究和应用研究指明方 向, 引领建立面向未来和面向世界的研究生态系统, 成为 大学、研究机构和研究人员之间相互促进的平台. NRF 资 助范围包括自然科学、生命科学、医学、工学、信息通信 及交叉学科五大领域. NRF 资助体系为三级学科结构, 按 照审查委员会领域(review board fields)划分, 分为部门 (division)-主评审委员会(chief review board)-评审委员会 (review board)3 个层级, 进而构成了韩国国家研究会资助 代码体系结构. 地球科学属于主评审委员会层级, 分属基 础科学与工程审查委员会领域下的自然科学部, 包含固体 
地球/地质科学、大气科学、海洋科学/极地科学和天文/空 间科学 4 个评审委员会(https://www.nrf.re.kr/eng/resources/ file/Basic). 与 NSFC 相比, NRF 的地球科学部下只含一级 代码, 而 NSFC 基金代码地球科学部下含三级代码. 因此, $\mathrm{NRF}$ 形成了地球科学为起点的指南引导评审体系, 结构相 对简单, 更多的是以指南引导进行项目申请.

\section{2 粗放申请代码方式}

日本和法国对科学基金的申请引导属于粗放申请代码 方式, 下面对其进行详细介绍.

\subsection{1日本学术振兴会}

日本学术振兴会(Japan Society for the Promotion of Science, JSPS) 是日本主要的科研资助机构之一, 旨在促进 基础研究到应用研究, 涵盖人文科学、社会科学和自然科 学. JSPS 以代码方式引导申请, 形成了单一体系的三级结 构, 按照字母顺序排列 $\mathrm{A} \sim \mathrm{K}$ 划分为 11 个理事会部分 (broad section); 按照数字顺序 1 65 划分为 65 个中等部分 (medium-section)及 311 个下级基础部分(basic section), 申 请代码采用 5 位数字 ${ }^{[4]}$. JSPS 以代码引导的方式指引申请 地球和行星相关领域, 与 NSFC 地球科学部对应的代码为 中等部分代码-17, 包括五大学科(等同于 NSFC 地球科学 部一级代码): 太空和行星科学(17010)、大气和水圈科学 (17020)、人文地理科学(17030)、固体地球科学(17040)和 生物地球科学 (17050) (https://www.jsps.go.jp/english/egrants/index.html). 由此可见, JSPS 代码体系相对简单, 按 一级代码体系结构进行学科布局.

\subsection{2 法国国家科研署}

法国国家科研署(Agence Nationale De Le Recherche, ANR) 是法国资助科学研究和创新的重要机构, 促进基础 研究的贡献在欧洲乃至世界范围占有一席之地. ANR 申请 代码体系划分为 8 个科学领域(scientific fields), 科学领域 下分 49 个研究主题(research themes). 8 个科学领域包括环 境科学、能源与材料科学、生命科学、社会学与人文学、 数字科学、数学及其相互作用、物质、高能物理学、地球 和宇宙科学以及交叉学科等领域, 代码为 $\S$ E.1 § E.8. 而 $\S$ E. 8 为交叉学科领域, 包含 13 个分支学科, 使学科之间相 互融合. ANR 涉及地球科学相对分散, 没有独立的科学领 域, 而是分散在环境科学领域(§ E.1)和物质、高能物理学、 地球和宇宙科学领域 (§ E.7). 环境科学领域主要包含流体 与固体地球和动态地球相关学科, 代码为 $\S$ E.1, Theme 1.1 和§ E.1, Theme 1.2. 物质、高能物理学、地球和宇宙科学 领域包含行星科学和地球结构与历史学科, 代码为 $\S \mathrm{E} .8$, Theme 7.3(https://anr.fr/fileadmin/aap/2019/aapg-anr-2019Guide-en). 由此可见, ANR 代码资助体系与日本相似, 为 一级代码体系结构.

\section{3 细分申请代码方式}

德国、欧盟、澳大利亚和新西兰对基础科学研究的 资助工作主要采用细分代码的形式进行申请引导和学科 布局.

\subsection{1 德国研究基金会}

德国研究基金会 (Deutsche Forschungsgemeinschaft, DFG)实行执行董事会的组织结构形式, 下设行政部、中心 管理部、国际事务与综合活动部、科学事务部以及协调计 划与基础设施部，科学事务部负责科学基金相关事务. 资 助范围包括人文社会科学、生命科学、自然科学和工程科 学四大领域.

DFG 主要采用代码引导申请, 四大领域的代码体系具 有统一性, 并采用同一套代码体系. DFG 基金申请代码体 系采用四级结构, 按照科学学科(scientific disciplines)-研 究领域(research areas)-评审委员会(review boards)-学科领 域(subject areas)进行划分. 四级代码体系结构从粗到细依 次为: 一级科学学科 4 个, 二级研究领域 14 个, 三级评审 委员会 49 个, 四级学科领域 211 个. 为了能够及时反映学 科发展, DFG 代码体系大体上每 4 年调整一次. DFG 代码 体系中自然科学学科(代码 3)包含二级地球科学领域(代码 34 ), 二级研究领域地球科学(代码 34)包含 6 个三级评审委 员会(代码 313 318), 每个评审委员会包含 1 2 个学科领域, 共 9 个学科领域 (https://www.dfg.de/en/index.jsp.). DFG 代 码体系中二级研究领域地球科学相当于 NSFC 中地球科学 学部, 三级评审委员会相当于 NSFC 学科一级代码, 学科 领域相当于 NSFC 学科二级代码. 由此可见, DFG 属于细 分代码方式引导申请, 为二级申请代码体系结构.

\subsection{2 欧洲研究理事会}

欧洲研究理事会(European Research Council, ERC)资 助欧洲所有领域的前沿科学研究, 是欧洲各国科学研究资 助机构的补充. ERC 为三级代码结构体系, 按照科学管理 部门(3 个)-研究领域(25 个)-学科方向(337 个)进行划分. 三 大管理部门分别是自然科学与工程(physical sciences and engineering)、生命科学(life sciences)和社会与人文科学 (social sciences and humanities), 代码分别为 PE、LS 和 SH. $\mathrm{ERC}$ 代码体系中与地球科学研究相关的领域是地球系统 科学, 属于自然科学与工程管理部门, 代码为 PE10, 研究 领域含 20 个学科方向, 学科代码按照 PE10_1 PE10_20 的 顺序排列, 包含大气、海洋、陆地圈等各学科方向 (https://erc.europa.eu/about-erc/mission). ERC 代码体系为 简单的一级代码体系结构.

\subsection{3 澳大利亚研究理事会和新西兰商业、创新与就 业部}

2008 年澳大利亚统计局(Australian Bureau of Statistics, $\mathrm{ABS}$ )和新西兰统计局(Stats NZ)联合发布了澳大利亚和新 
西兰的标准研究代码分类(ANZSRC 2008). ANZSRC 2008 代码分类包含 3 种类别: 活动类型(type of activity, ToA 2008)、研究领域(fields of research, FoR 2008)和社会-经济 目标(socio-economic objectives, SEO 2008). 为了保证代码 分类及时反映当前新兴的研究领域, 并提高代码分类的覆 盖范围、连贯性和一致性, 2020 年, ABS、Stats NZ、澳大 利亚研究理事会(Australian Research Council, ARC)以及新 西兰商业、创新与就业部(Ministry of Business, Innovation \& Employment, MBIE)再次联合发布了标准研究代码分类 (ANZSRC 2020)取代 ANZSRC 2008.

ToA 2020 根据研究成果对研究和实验开发进行分类, 是一个平面分类方式, 分为 4 种资助类别: 纯基础研究、 战略基础研究、应用研究和实验开发.

FoR 2020 根据常识领域和/或研究与实验开发的方法 进行分类, 为三级结构: 部门(divisions)-学科(groups)-领域 (fields), 设置为 23 个部门、213 个学科和 1967 个领域, 较 FoR 2008 的 22 个部门、157 个学科和 1238 个领域都有所 增加, 其中部门代表最广泛的研究领域, 学科和领域则代 表更加细分的分类. 部门分类是一个二位代码, 学科分类 是四位代码, 领域分类是六位代码. 地球科学部门(代码 37) 包含 8 个学科代码(代码 3701 3708) 以及其他地球科学学 科(代码 3709), 而学科又包含 54 个领域和 1 个其他地球科 学领域和 1 个未分类领域(学科分类不清楚都可以归人此 类), 另外每个学科还包含一个未分类领域代码(领域分类 不清楚都可以归人此类, https://www.arc.gov.au/anzsrcreview). FoR 2020 代码体系中地球科学部门相当于 NSFC 中地球科学学部, 学科相当于 NSFC 学科一级代码, 领域 相当于 NSFC 学科二级代码. 由此可见, FoR 2020 代码体 系是二级代码, 比 NSFC 代码体系中的三级代码也更为 简单.

SEO 2020 根据数据提供者或研究人员认为的研究和 实验开发的预期目标或结果进行分类, 也为三级结构: 部 门(divisions)-学科(groups)-目标(objectives). 部门分类也是 一个二位代码, 学科分类是四位代码, 目标分类是六位代 码, 与 SEO 2008 相比把行业取消了, 直接由部门代码开始, 这样与 FoR 2020 成一套代码体系. SEO 2020 包含 19 部门、 128 个学科和 840 个目标.

\section{3 国家自然科学基金委员会}

NSFC 地球科学部的学科体系及申请代码在 1986 2020 年的 30 余年里经历了 6 次代码调整 ${ }^{[2]}$, 申请代码由初 期的 5 个一级学科代码, 发展到 7 个一级学科代码, 95 个 二级代码, 65 个三级代码的细分代码体系. 现行的地球科 学部申请代码主要遵循“部门学科-分支学科-研究领域”的 分类规则. 下面对 NSFC 代码体系中地球科学部代码进行 介绍.
地理学学科(D01)下设置了 8 个二级代码, 依据骨干学 科划分了自然地理学、人文地理学、遥感机理与方法、地 理信息系统、测量与地图学 5 个二级代码; 按交叉学科划 分了景观地理学、自然资源管理 2 个二级代码; 按国家需 求划分了区域可持续发展 1 个二级代码, 共 8 个二级代码, 而在 8 个二级代码下还设置了 23 个三级代码.

地质学学科(D02)下设置了 19 个二级代码, 依据支撑 学科划分了古生物学和古生态学、地层学、矿物学(含矿物 物理学)、岩石学、沉积学和盆地动力学、构造地质学与活 动构造、大地构造学、第四纪地质学、前寒武纪地质学 9 个二级代码; 依据国家需求划分了矿床学、煤地质学、石 油、天然气地质学、水文地质学、工程地质学、火山学与 地热地质、勘探技术与地质钻探学 7 个二级代码; 依据地 球系统视角划分了行星地质学、生物地质学以及数学地质 学与遥感地质学 3 个二级代码. 此外, 在二级代码下设置 了 7 个三级代码.

地球化学学科(D03)下设置了 14 个二级申请代码, 依 据基础理论划分了同位素地球化学、微量元素地球化学、 同位素和化学年代学、气体地球化学、油气地球化学、纳 米与分子地球化学 6 个二级代码; 依据技术方法划分了实 验地球化学和计算地球化学 2 个二级代码; 依据应用领域 划分了岩石地球化学、矿床地球化学、宇宙化学与比较行 星学、油气地球化学、沉积地球化学、生物地球化学和化 学地球动力学 6 个二级代码.

地球物理学和空间物理学学科(D04)下设置了 13 个二 级代码, 按分支学科划分了大地测量学(大地测量学和工 程测量学)、固体地球物理学(地震学、地磁学、地球电磁 学、重力学、热力学、地球内部物理学、地球动力学)、空 间物理学(空间物理学、空间环境和空间天气)、应用地球 物理学(应用地球物理学)、实验与仪器(地球物理学和空 间物理学实验与仪器). 在二级代码下还设置了 11 个三级 代码.

大气科学学科(D05)设置了 15 个二级代码, 依据分支 学科划分了天气学、气候与气候系统、古气候模拟与动力 学、大气动力学、大气物理学、大气化学、生态气象、行 星大气；依据支撑技术划分了大气观测、遥感和探测技术 与方法、大气数据与信息技术、大气数据模式发展、地球 系统模式发展; 依据发展领域划分了气候变化及影响与应 对、大气环境与健康气象、应用气象学.

海洋科学学科(D06)设置了 15 个二级代码, 依据分支 学科划分了物理海洋学、海洋化学、海洋地质学与地球物 理学、生物海洋学与海洋生物资源、海洋生态学与环境科 学、河口海岸学; 依据支撑技术划分了海洋遥感、海洋物 理与观测探测技术、海洋数据科学与信息系统; 依据发展 领域划分了海洋系统与全球变化、海洋工程与环境效应、 海洋灾害与防灾减灾、海洋能源与资源、海陆统筹与可持 续发展、极地科学. 
环境地球科学学科(D07)设置了 11 个二级代码, 按基 础学科划分为土壤学、环境水科学、环境大气科学、环境 生物科学; 按交叉学科划分为工程地质环境与灾害、环境 地质学、环境地球化学; 按前沿领域划分为污染物行为过 程与环境效应、第四纪环境、环境变化与环境预测; 按国 家需求划分了区域环境质量与安全. 11 个二级代码下又设 置了 24 个三级代码.

综上所述, NSFC 地球科学部各学科申请代码划分方式 无统一标准, 共设 95 个二级代码, 65 个三级代码. 繁琐精细 的代码划分不利于体现学科内部的综合性, 也制约了学部 学科与学科间, 以及与其他学部间的交叉融合. 此外, 学科 内部代码还存在分支学科不完整的情况, 使得学科体系发 展不均衡; 学科代码中分支学科与发展领域混淆、技术与应 用混淆 ${ }^{[3]}$, 造成科研人员总体重技术、偏理论, 重应用、轻 视基础科学突破的局面. 虽然地球科学部代码近年来频繁 调整, 但从引导申请结果来看, 仍存在现行代码体系对新时 代科技前沿布局不足, 对关键理论与技术导向不明的情况.

作为 NSFC 三大改革任务之一, 以优化学科布局为基 础的申请代码调整的根本目标是最大限度地解放和激发 科技作为第一生产力所蕴藏的巨大能量. 申请代码的优化 调整应基于提高申请代码的包容性和覆盖面, 支持跨学 科、跨学部的交叉研究; 厘清申请代码整体架构和逻辑关 系，从“分支学科”、“支撑技术”和“发展领域”分别体现对基
础前沿科学、应用技术和国家民生需求的引领作用.

\section{4 讨论与思考}

国际上主要科研项目资助机构申请引导与代码特征如 图 2 所示. 美国、英国、韩国、日本、法国申请引导代码 体系比较粗, 德国、欧盟、澳大利亚、新西兰和中国申请 代码体系比较细. 申请引导主要可以归为三类: 指南引导、 粗放代码引导和细分代码引导. 指南引导申请具有方式灵 活, 可以针对学科前沿与国家需求及时布局的优势. 而代 码引导申请有利于学科体系自洽和传承发展. 但是代码引 导申请划分过细虽然有利于智能化管理, 充分发挥大数据 人工智能的优势, 但会制约交叉融合, 导致学科布局的综 合性和交叉性不足. 国际上, 只有中国自然科学基金存在 设立大量三级代码进行申请引导的情况. 下面结合 NSFC 地球科学部 2020 年度各代码申请量分布, 讨论现行代码 申请划分过细存在的问题以及代码引导申请改革的可行 性与必然性.

图 3 给出了 2020 年度 NSFC 地球科学部申请项目数按 末级申请代码的分布情况. 地球科学部受理基金总数为 

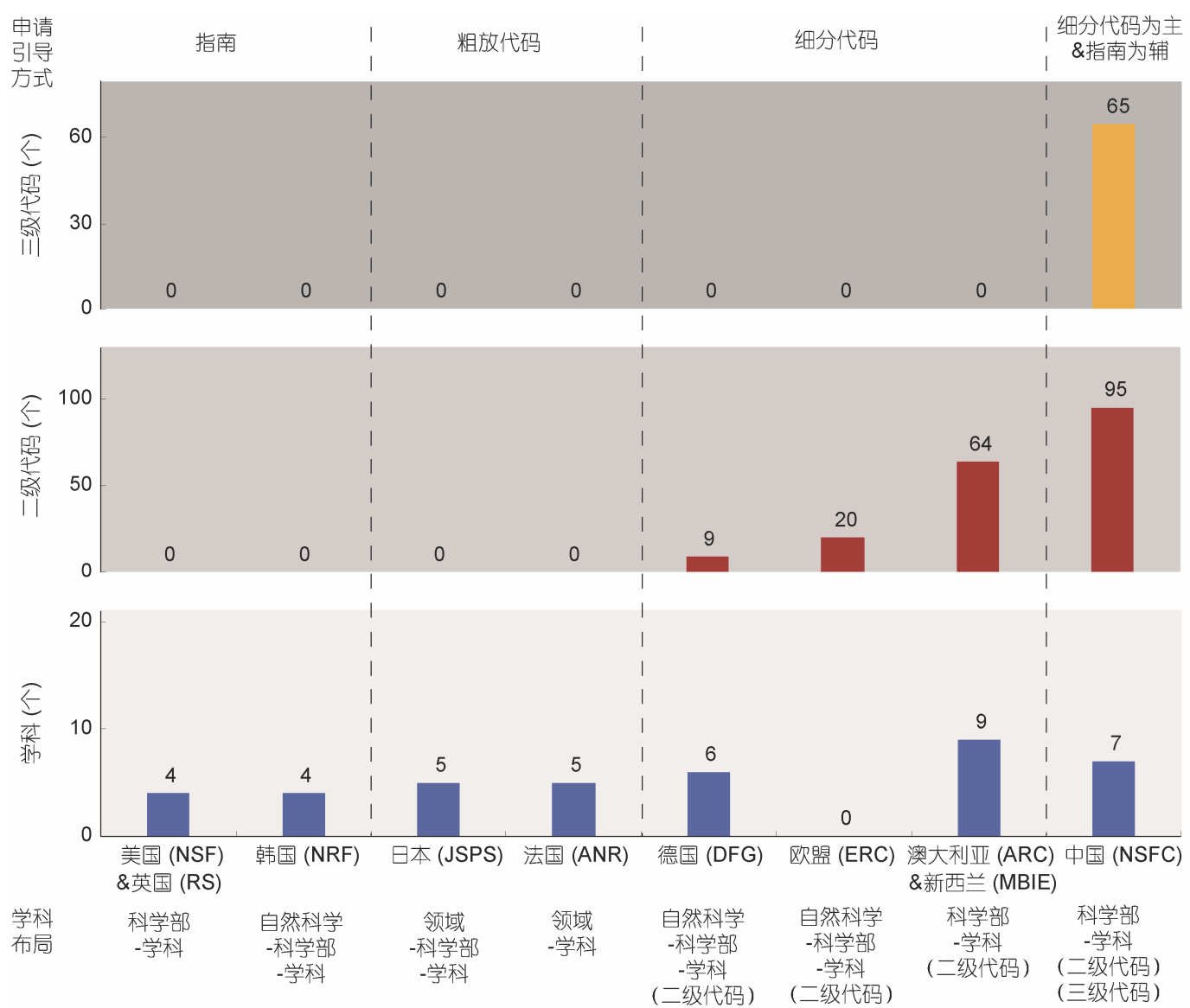

图 2 (网络版彩色)中国与国外基金申请代码特点

Figure 2 (Color online) The characteristics of application codes of the science foundations and agencies

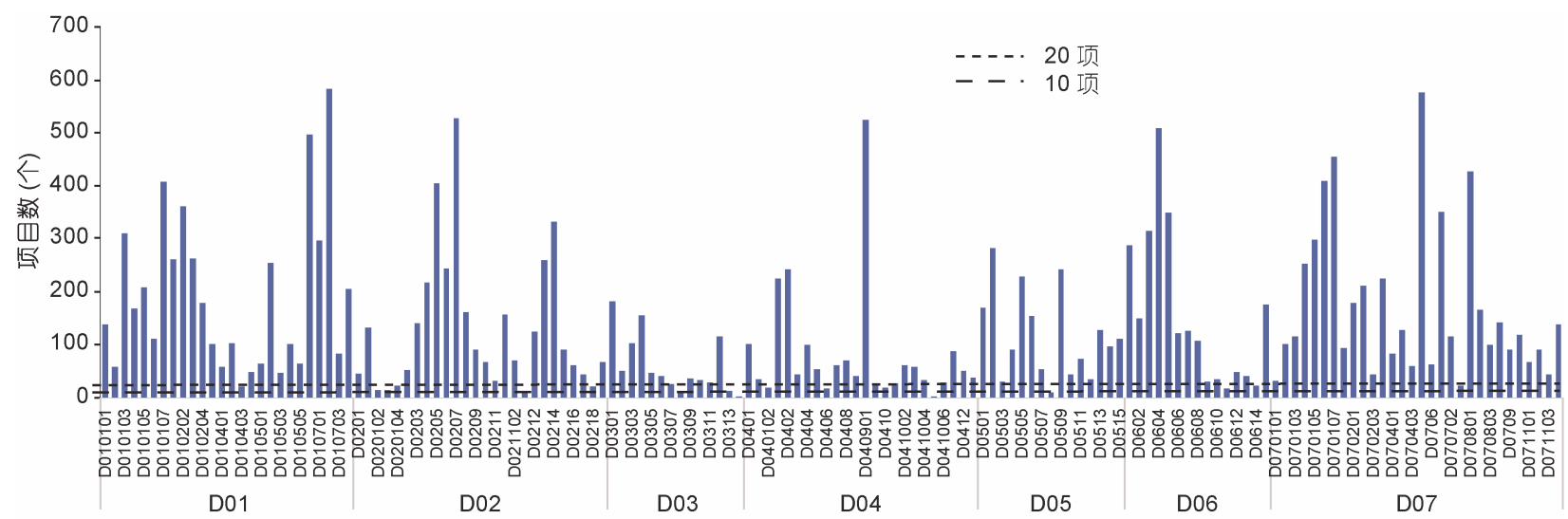

图 3 (网络版彩色) 2020 地球科学部申请量分布. 基于末级申请代码和集中受理期受理项目数

Figure 3 (Color online) The distribution of applications from the department of earth sciences of NSFC in 2020. Based on the final application codes and number of accepted items during the centralized acceptance period

20586 项，在二级代码下有 10731 项，平均每个代码下分布 113 项; 三级代码为 9711 项, 平均每个代码 149 项; 12 个 末级代码的申请量低于 20 项, 4 个末级代码的申请量低于
10 项, 代码 D0314(化学地球动力学)申请量最少, 为 1 项, 代码 D010702(遥感信息与应用)申请量最多, 为 584 项. 地 球化学(D03)、地球物理学与空间物理学(D04)和大气科学 
(D05)3 个学科只有二级代码, 三级代码的申请量主要来自 地理学(D01)和环境地球科学(D07). 由此可见, 地球科学 部申请代码和学科布局客观上存在代码申请量分布极不 平衡, 一些代码申请量过多, 而些却过少. 同时, 由于地 球科学部以二级学科代码为主 (95 个), 只有 4 个学科进一 步细分设置了 65 个三级申请代码, 取消三级申请代码难 度小, 实践上具有可操作性. 通过学科代码改革进行学术 布局优化既可行, 也必要.

需要特别指出的是, 从 2018 年中国 NSFC 与美国 NSF 地球科学部的人力资源对比来看, NSFC 地球科学部的固 定人员 12 人, 合同制人员 9 人, 兼聘人员 $30 \sim 40$ 人, 申请 项目总数为 17158 项, 资助项目数为 4279 项, 人均工作量 约为 817 项/人. 美国 NSF-GEO 董事会人员有 18 人, 项目 管理人员有 127 人(约 $55 \%$ 为固定人员), 申请项目总数为 3775 项, 资助项目数为 1407 项, 人均工作量约为 29 项/人. 因此, 中国 NSFC 在现有人力资源情况下, 是不可能像美 国 NSF一样, 完全通过指南引导来进行申请引导和学科布 局, 实现学科优化布局调整, 以及资助项目的实时跟踪与 精细化管理. 我国科学基金申请代码的改革, 必须在现有 人力资源极其有限的情形下, 保证申请代码具有适度细化, 以满足计算机智能化协助的实际需要.

还应该强调的是大国基础科学研究与小国关注的不同, 中国需要全面发展基础研究, 而不是集中在几个小的领域. 中国科学基金制在现阶段的改革和未来完善过程中, 需要 重点学习和借鉴美国 NSF 经验. 在学科布局方面, 现阶段 $\mathrm{NSFC}$ 设置的一级学科 (7个)与美国 NSF(4 个)相比偏多, 固 体地球(地质、地化、矿产、油气等能源矿产从建国初期起 就是我国特别关注的领域)和地理(师范院校均有地理学)
学科偏大, 而大气、海洋和极地学科偏小. 但在地球系统 科学范畴内, 大气、海洋与固体地球占有等同的比重. 随 着中国地球科学基础研究的发展和强大, 值得在未来的学 科布局中更加重视学科发展的平衡. 美国 NSF 明确为指南 导向, 与他们重视科学战略研究和明确资助部署顶层设计, 在实际工作中以推动基础科学研究为重, 而不是以学科现 实格局为重有密切关系. 目前, 我国 NSFC 地球科学部正 在全方位加强地球科学顶层战略成果和科学基金资助布 局的统筹考虑, 围绕 “宜居地球” 总体战略目标, 以深地、 深海、深空、地球系统 “三深一系统” 构成四梁, 以地球 科学优先支持领域组成八柱. 在这一总体发展战略规划的 指导下, 通过指南引导的方式在川藏铁路重大基础科学问 题、极地基础科学前沿、新型冠状病毒肺炎疫情中的地球 科学重大基础科学问题、黄河流域生态保护与可持续发 展、深时地球科学知识图谱与知识演化等领域及时部署重 大专项, 很好发挥了国家自然科学基金在解决国家重大需 求和国际科学前沿背后的基础科学问题方面的支撑作用. 未来, 我们应该进一步完善重大类项目科学问题的凝练机 制和管理办法, 更加重视指南引导在关键领域中的资助效 能，全面推进地球科学基金事业的繁荣. 总的来说，申请 代码优化要同时兼顾申请引导合理性和管理适用性的需 要, 申请代码设置要具有学科自洽、稳定传承、支撑服务、 新兴交叉及国家需求等特征. 从基础研究队伍与人力管理 资源规模考虑, 需要代码从粗放申请代码-细分申请代码智能辅助等 3 个关键要素进行优化设置, 才能有利于优化 学科布局, 提升基础研究能力, 完成科学基金管理改革的 核心使命, 实现构建理念先进、制度规范、公正高效的科 学基金治理体系的目标.

\section{推葆阅读文献}

1 National Natural Science Foundation of China. National Natural Science Fund Guide to Programs 2020 (in Chinese). Beijing: Science Press, 2020. 30-35 [国家自然科学基金委员会. 2020 年度国家自然科学基金项目指南. 北京: 科学出版社, 2020. 30-35]

2 Zhang C L, Zheng Y M, Fan W J, et al. The historical evolution and outlook for the application code of geography discipline, NSFC (in Chinese). Acta Geogr Sin, 2019, 74: 191-198 [张朝林, 郑袁明, 范闻捷, 等. 国家自然科学基金地理学科申请代码的历史沿革与发 展. 地理学报, 2019, 74: 191-198]

3 Liu Z, Ding A J, Zhang R H. Adjusting application codes and optimizing funding layout for the discipline of atmospheric sciences in the National Natural Science Foundation of China (in Chinese). Chin Sci Bull, 2020, 65: 1068-1075 [刘哲, 丁爱军, 张人禾. 调整国家自 然科学基金申请代码, 优化大气科学资助布局. 科学通报, 2020, 65: 1068-1075]

4 Wang Y L, Wang M H, Zheng Z M, et al. Classification code systems of research funding institutions in developed countries and its enlightenment to China (in Chinese). Sci Found Chin, 2020, 34: 237-242 [王芗莉, 王美惠, 郑知敏, 等. 发达国家科学基金组织申请代 码体系评述及其启示. 中国科学基金, 2020, 34: 237-242] 


\title{
Discipline layout and application guide for earth sciences from leading international science foundations and agencies
}

\author{
Chaolin Zhang*, Yuanming Zheng, Xibo Wang, Jukun Xiong, Lilan Zhang, Qingwei Zhou \& Ruonan Li \\ Department of Earth Sciences, National Natural Science Foundation of China, Beijing 100085, China \\ * Corresponding author, E-mail: zhangcl@nsfc.gov.cn
}

According to the principle of being "derived from the logical structure of the knowledge system and promoted through the integration and application of knowledge", advancement in interdisciplinary research is one of the three core tasks of the deepening reform of the National Natural Science Fund in the new era. This article takes an international vision by first investigating the disciplinary layout and application guide for the field of earth sciences offered by leading international science foundations and agencies including the National Science Foundation, United States (NSF); National Research Foundation of Korea (NRF); Japan Society for the Promotion of Science; Agence Nationale De Le Recherche; Deutsche Forschungsgemeinschaft (DFG); European Research Council; Australian Research Council; Ministry of Business, Innovation \& Employment; and National Natural Science Foundation of China (NSFC). These application guides include categories of guidelines, extensive application codes, and subdivided application codes. Compared with the existing hierarchical structure for application codes in the field of earth sciences at NSFC, the feasibility and necessity of promoting the optimization of the disciplinary layout and reform of application codes are discussed. Then, it is proposed that the disciplinary layout should be based on the current conditions as well as the future developmental needs of China and that the optimization of application codes should consider the needs of both application guidance rationality and management applicability. Moreover, the setting of application codes should include self-consistent disciplines; exhibit stable inheritance; and support services, emerging intersections, and national needs. To optimize the disciplinary layout, improve the basic research capabilities, and account for the scale of basic research teams and human management resources, the application codes need to be optimized on the basis of three key factors: Extensive application codes, subdivided application codes, and intelligent assistance. Only in this way can the core mission of science foundation management reforms be fulfilled and the goal of building a science foundation management system with advanced concepts, standardized systems, fairness, and efficiency be achieved. In the future, NSFC should focus on the differences between basic scientific research conducted by large and small countries, pay more attention to balanced development in the discipline layout, develop basic general research, and comprehensively promote the growth of the earth science fund. During the past two years, under the guidance of clear, overall strategic planning and top-level design, NSFC's Department of Earth Sciences has deployed multiple major projects by guidelines, such as those for the major basic science projects of the Sichuan-Tibet railway and frontier projects of basic polar science as well as special projects related to 2019-nCoV research, ecological protection and sustainable development of the Yellow River Basin, and deep-time earth science knowledge graphing and knowledge evolution. These established projects have played key roles in enabling NSFC to meet the major national needs and push forward international scientific frontiers. In the future, NSFC should continue to pay significant attention to strategic research and the top-level design of funding deployment. Moreover, the foundation should strengthen the overall consideration of the top-level strategic results of earth sciences and the layout of the science fund. In practice, the focus should be on the promotion of basic scientific research rather than servicing the other needs of different disciplines. By further improving the condensed mechanism and management methods of the major projects of earth sciences, the important role of guidelines in funding effectiveness will be strengthened. This article can provide the necessary international vision and strategic support for the reform of the application codes of NSFC.

science foundation, earth sciences, disciplines optimization, application codes

doi: 10.1360/TB-2020-1366 